\title{
Numerical investment in sex and caste by stingless bees (Apidae: Meliponini): a comparative analysis
}

\author{
Pérsio de Souza Santos-FilHo ${ }^{\text {, }}$, Denise de Araujo Alves ${ }^{\mathrm{a}}$, André ETEROVIC $^{\mathrm{a}, \mathrm{b}}$, \\ Vera Lucia IMPERATRIZ-FonSECA ${ }^{\mathrm{a}, \mathrm{c}}$, Astrid de Matos Peixoto KLEINERT ${ }^{\mathrm{a}}$ \\ ${ }^{\text {a }}$ Departamento de Ecologia, Instituto de Biociências, Universidade de São Paulo, 05508-900 São Paulo, SP, \\ Brazil \\ ${ }^{\mathrm{b}}$ Colégio Bandeirantes, São Paulo, Brazil \\ ${ }^{c}$ Departamento de Biologia, Faculdade de Filosofia Ciências e Letras de Ribeirão Preto, Universidade de São \\ Paulo, 14090-901 Ribeirão Preto, SP, Brazil
}

Received 2 October 2005 - revised 11 January 2006 - accepted 20 January 2006

\begin{abstract}
Sex and caste allocation by five stingless bee species was investigated. The study included species that build royal cells (RCP: Plebeia remota and Schwarziana quadripunctata) and species that do not (RCA: Melipona asilvai, M. bicolor and M. subnitida). Allocation to gynes, males and workers was assessed by linear regression slopes and simple ratios. RCP had higher allocation to males, and RCA had higher allocation to gynes and workers. In both groups, a negative correlation in males vs. workers suggested a prevalent opportunity cost, which may hinder colony growth and/or colony fission.
\end{abstract}

stingless bees / Meliponini / sex ratio / worker production / numerical allocation

\section{INTRODUCTION}

Sex ratio evolution at the population level in Hymenoptera with independent nest founding behavior has been the subject of numerous studies in evolutionary biology since Trivers and Hare (1976) combined kin selection theory with the Fisherian view on sex ratio equilibrium (e.g. Benford, 1978; Frank, 1987; Crozier and Pamilo, 1996; Queller and Strassmann, 1998; Chapuisat and Keller, 1999; Mehdiabadi et al., 2003). Considerably less attention has been given to sex investment in hymenopteran species with swarm founding (but see Oster et al., 1977; Macevicz, 1979; Craig, 1980; Bulmer, 1983; Page and Metcalf, 1984; Pamilo, 1991; Crozier and Pamilo, 1996). This is due to difficulties in ascertaining the additional investment in the entourage of workers which accompany the queen in nest founding, as realized by Hamilton (1975,

Corresponding author: P.S. Santos-Filho, pssantos@ib.usp.br see also Craig, 1980; Boomsma and Grafen, 1991). Focus on swarm founding species highlights the importance of workers in the reproduction of these eusocial insects. It is widely appreciated that workers constitute the ergonomic basis of the colony, and their role in the production of reproductives is acknowledged as fundamental (Oster and Wilson, 1978). However, only recently the investment in workers began to be explicitly considered in allocation models for eusocial hymenopterans (Pamilo, 1991; Crozier and Pamilo, 1996; Bourke and Chan, 1999; Herbers et al., 2001; Reuter and Keller, 2001).

Resource allocation has been explicitly incorporated in modeling (i) queen-worker conflict over maintenance-growth vs. reproduction, (ii) queen-worker conflict over sex ratio allocation (Pamilo, 1991; Reuter and Keller, 2001), (iii) decisions over allocation of workers to swarms (Pamilo, 1991; Crozier and Pamilo, 1996), and (iv) intra-colony conflicts over caste determination (Reuter and Keller, 2001; Wenseleers et al., 2003). Focus has been 
mainly directed towards optimal decisions on allocations based on kin selection models. Less attention has been given to the costs involved in these decisions, although they are the basis of the models' assumptions and impinge both on individuals and on the colony.

In the present work, the partitioning of the resource allocation equations examined by resource allocation models (Pamilo, 1991; Reuter and Keller, 2001; Wenseleers et al., 2003) were used as a framework to obtain a detailed view of numerical and proportional allocation to gynes, workers and males in some stingless bees. It was not our aim to test the models of Pamilo (1991) and Reuter and Keller (2001), as they refer either to independent nest founding species (Reuter and Keller, 2001) or to specific questions related to fission (Pamilo, 1991). Instead, the analyses were focused on the diverse allocation partitionings of these models (which are independent of the nest founding mode), so as to provide a clear relationship between the present analyses and the extant resource allocation models' structures. However, in the case of the Wenseleers et al. (2003) model, cost assumptions were also examined, as it directly addressed allocation to gynes in swarm founding species.

In swarm founding species, queen and workers are theoretically expected to be aligned in their interests regarding the production of gynes, resulting in extremely low allocation to gynes among female brood (see Craig, 1980; Pamilo, 1991; Bourke and Ratnieks, 1999; Wenseleers et al., 2003). As expected, those stingless bees that rear gynes in royal cells have only a very low investment in gynes, e.g. Tetragonisca angustula (van Veen and Sommeijer, 2000) and Trigona ventralis (Chinh and Sommeijer, 2005). Some species (as Plebeia remota and Schwarziana quadripunctata) build royal cells and their queens are generally much larger than workers. In addition, such species produce miniature queens which emerge from normal-sized cells that are also used to produce workers and males (see Ribeiro et al., in this Special Issue). In Melipona, as there are no royal cells, gynes are reared in normal-sized cells and they are slightly smaller than workers at emergence (e.g. Wenseleers et al., 2004a).
The major aim of this work is to contrast proportional and numerical allocations to each sex and caste of some species that build royal cells and also rear miniature queens ( $P$. remota and $S$. quadripunctata) with those species that do not build royal cells (M. asilvai, M. bicolor and $M$. subnitida), considering Melipona gynes as analogous to miniature gynes (see Wenseleers et al., 2003; Wenseleers and Ratnieks, unpublished data). Therefore, these two groups of species allow a direct assessment of the effect of presence vs. absence of royal cells in the investment to sexes and castes, within the framework generally used in resource allocation models.

\section{MATERIALS AND METHODS}

Five stingless bee species were studied: Melipona asilvai, M. bicolor, M. subnitida, Plebeia remota, and Schwarziana quadripunctata. In the first three, royal cells are absent and they were grouped under the acronym RCA. In the other two, royal cells are present and the label RCP was used. These groups resemble the tribes Meliponini and Trigonini defined by Moure (1961), based on the state of the same character. However, these taxa do not reflect the latest findings on stingless bee phylogeny (Michener, 2000; Silveira et al., 2002; Arias et al., 2003; Costa et al., 2003).

Nests of M. bicolor (from Cunha, São Paulo State), P. remota (Cunha and Prudentópolis, Paraná State) and $S$. quadripunctata (Cunha and Cotia, São Paulo State) were brought to the University of São Paulo Bee Laboratory, Brazil, where they were maintained in wooden observation hives. Isolated brood combs of M. asilvai and M. subnitida (Jardim do Seridó, Rio Grande do Norte State) sent to the lab were also used in the analyses. These species were subject to a simultaneous, longitudinal study at one single place, except for $M$. asilvai and $M$. subnitida. These rare conditions for stingless bee studies allow an unusual degree of homogeneity for comparative purposes.

The production of gynes, males, and workers was studied through the examination of living pupae in brood combs (Koedam, 2003) with at least 35 cells, sampled during 2003-2004. Sex and caste were determined through diagnostic morphological characteristics. The sampling scheme was heterogeneous in terms of number of colonies, number of brood combs examined and number of 
Table I. Total number of cells $\left(N_{\mathrm{c}}\right)$, workers $\left(N_{\mathrm{w}}\right)$, gynes $\left(N_{\mathrm{g}}\right)$, and males $\left(N_{\mathrm{m}}\right)$ in brood combs from colonies of stingless bees recorded during 2003-2004.

\begin{tabular}{lccccccc}
\hline Species & $N_{\mathrm{c}}$ & $N_{\mathrm{g}}$ & $N_{\mathrm{m}}$ & $N_{\mathrm{w}}$ & Brood combs & Colonies & Number of months \\
\hline M. asilvai & 1719 & 107 & 302 & 1310 & 15 & 14 & 3 \\
M. bicolor & 11745 & 724 & 728 & 10293 & 97 & 18 & 12 \\
M. subnitida & 2523 & 196 & 179 & 2148 & 29 & 29 & 3 \\
P. remota & 11184 & 9 & 2966 & 8209 & 37 & 5 & 9 \\
S. quadripunctata & 14578 & 81 & 2651 & 11846 & 96 & 20 & 13 \\
\hline
\end{tabular}

months in which the colonies were sampled (Tab. I). Data pertaining to all brood combs of each colony were pooled to ensure independence for analysis at colony level and also to smooth out any seasonal variation in the production of individuals, especially males, which is known to occur in these five species (e.g. Koedam et al., 1999; Alves, 2004; Alves et al., 2004; Velthuis et al., 2005). Colonies were represented by $1-12$ brood combs.

Sex ratio investment theory deals with the allocation of resources to each sex, and thus demands investment to be known in terms of mass and/or energy allocated (e.g. Trivers and Hare, 1976) and not simply the numerical allocations. However, numerical allocation is very simply determined, and allows interesting inferences to be made. The completed brood comb has a fixed proportion of gynes $\left(p_{\mathrm{g}}\right)$, males $\left(p_{\mathrm{m}}\right)$, and workers $\left(p_{\mathrm{w}}\right)$. These ratios and others, used in published allocation models (Pamilo, 1991; Reuter and Keller, 2001; Wenseleers et al., 2003), are defined in Table III and termed ratio allocations in a series of analyses, as follows. MannWhitney test (MW), followed by Levene test were employed to verify differences between the two groups (RCA and RCP). The variance attributable to differences between groups and species was also partitioned. In addition, the variability of ratio allocations was computed through the coefficient of variation ( $C V$, Sokal and Rohlf, 1998).

The structure of resource allocation models' equations (Pamilo, 1991; Reuter and Keller, 2001; Wenseleers et al., 2003) allows their direct use within multiple and bivariate linear regression frameworks, to which the brood comb data can be readily fitted (Tab. II). The total number of cells $\left(N_{\mathrm{c}}\right)$ is perfectly reflected as the sum of the number of gynes, males, and workers $\left(N_{\mathrm{c}}=N_{\mathrm{g}}+N_{\mathrm{m}}+N_{\mathrm{w}}\right.$, or $N_{\mathrm{c}}=p_{\mathrm{g}} N_{\mathrm{c}}+p_{\mathrm{m}} N_{\mathrm{c}}+p_{\mathrm{w}} N_{\mathrm{c}}$ ). Note that $N_{\mathrm{c}}$ refers to the total number of cells of all brood combs sampled per colony.

This natural partitioning allows its expression as a multiple linear regression in which both the ad- ditive structure of the independent variables is assured, but also in which $100 \%$ of the variance in the total number of cells of the brood comb is explained. The numerical allocation of sex and caste can also be examined for each proportional allocation through bivariate linear regression analysis (for an analogous use of regression, see Tschinkel, 1993). Thus, the production of gynes, males, and workers in brood combs was analysed using a bivariate regression approach, as the colony data points are independent, assuming that data were measured without error. Because they are counts, they were used as independent variables in the analyses.

The analytical structure of the models in Table II requires that the linear regression equations have a zero intercept. However, linear regressions through the origin, although biologically meaningful in the present case, have some undesirable properties such as the sum of residuals not being equal to zero (Quinn and Keough, 2002). So, a linear regression model was used with an intercept $a$, such that $N_{\mathrm{i}}=a+b_{\mathrm{i}} N_{\mathrm{c}}$, where $N_{\mathrm{i}}$ is the number of individuals in the $i$-th sex or caste and $b_{\mathrm{i}}$ is the slope, a value that corresponds to the mean proportional allocation. The comparison of these slopes between groups using non-transformed variables has been carried out with simple $t$-tests (Zar, 1999).

Analyses of the relationships between proportional allocations $\left(p_{\mathrm{i}}\right)$ in the non-hierarchical model (Tab. II) were made using as $p_{\mathrm{i}}$ the residuals of the appropriate regressions through partial regressions, henceforth termed residual allocations. Correlation analysis between residual allocations allows detection of the presence of opportunity costs, which can be defined as the costs incurred in foregoing the rearing of individuals of a given sex and caste due to the rearing of individuals of another sex or caste. Here the opportunity costs are directly examined in the same units, as residual allocations.

Reproductive allocation and sex ratio analyses were done with the residuals of partial regressions 


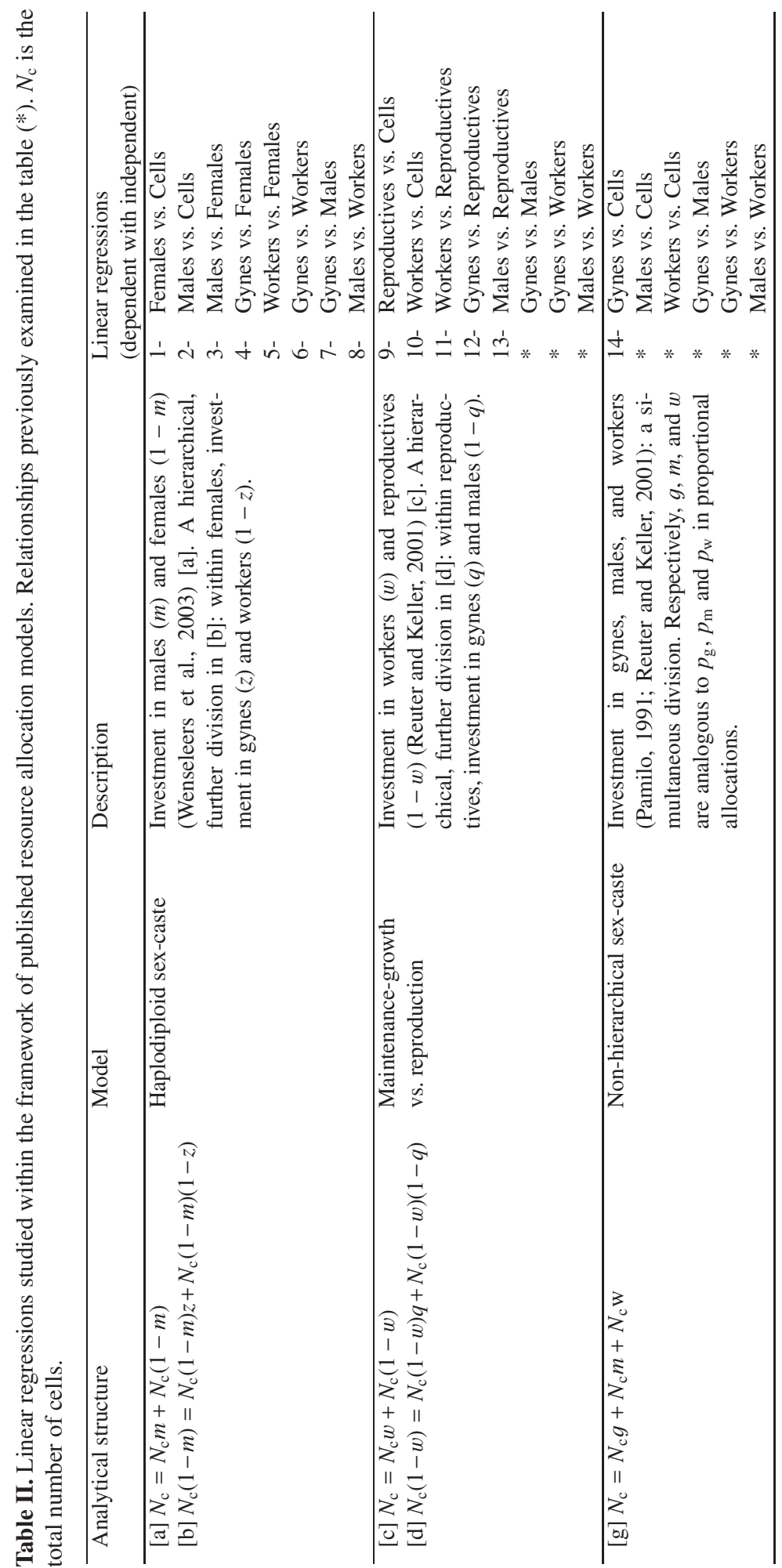


Table III. Ratio allocations (mean $\pm s d)$ in RCA $(n=61)$ and RCP $(n=24)$ colonies. $N_{\mathrm{c}}, N_{\mathrm{g}}, N_{\mathrm{m}}, N_{\mathrm{w}}, N_{\mathrm{typ}}$ and $N_{\min }$ are, respectively, the total number of cells, gynes, males, workers, typical gynes, and miniature gynes. Significant differences between groups $(* P<0.05)$.

\begin{tabular}{llll}
\hline Ratio allocation & Formulae & RCA & RCP \\
\hline$p_{\mathrm{g}}$ & $N_{\mathrm{g} /} N_{\mathrm{c}}$ & $0.071 \pm 0.005$ & $0.007 \pm 0.002$ \\
$*$ gynes & & $(0.01-0.22)$ & $(0.00-0.04)$ \\
\hline$p_{\mathrm{m}}$ & $N_{\mathrm{m}} / N_{\mathrm{c}}$ & $\begin{array}{l}0.082 \pm 0.015 \\
(0.00-0.45)\end{array}$ & $\begin{array}{l}0.167 \pm 0.030 \\
(0.00-0.40)\end{array}$ \\
males & $N_{\mathrm{w}} / N_{\mathrm{c}}$ & $0.847 \pm 0.015$ & $0.826 \pm 0.030$ \\
\hline$p_{\mathrm{w}}$ & & $(0.47-0.99)$ & $(0.59-1.00)$ \\
workers & $\left(N_{\mathrm{g}}+N_{\mathrm{w}}\right) / N_{\mathrm{c}}$ & $0.918 \pm 0.015$ & $0.833 \pm 0.030$ \\
\hline $1-p_{\mathrm{m}}$ & & $(0.55-1.00)$ & $(0.60-1.00)$ \\
females & $\left(N_{\mathrm{g}}+N_{\mathrm{m}}\right) / N_{\mathrm{c}}$ & $0.153 \pm 0.015$ & $0.175 \pm 0.030$ \\
\hline $1-p_{\mathrm{w}}$ & & $(0.01-0.53)$ & $(0.00-0.41)$ \\
reproductives & $N_{\mathrm{g}} /\left(N_{\mathrm{g}}+N_{\mathrm{w}}\right)$ & $0.079 \pm 0.005$ & $0.008 \pm 0.002$ \\
\hline$z$ & & $(0.01-0.23)$ & $(0.00-0.04)$ \\
$*$ gynes within females & $N_{\mathrm{w}} /\left(N_{\mathrm{g}}+N_{\mathrm{w}}\right)$ & $0.922 \pm 0.005$ & $0.992 \pm 0.002$ \\
\hline $1-z$ & & $(0.77-0.99)$ & $(0.96-1.00)$ \\
$*$ workers within females & $N_{\mathrm{m}} /\left(N_{\mathrm{m}}+N_{\mathrm{g}}\right)$ & $0.356 \pm 0.041$ & $0.771 \pm 0.080$ \\
\hline $1-q$ & $(0.00-0.89)$ & $(0.00-1.00)$ \\
$*$ males within reproductives & & & $0.001 \pm 0.002$ \\
\hline$z_{\text {typ }}$ & $N_{\mathrm{typ}} /\left(N_{\mathrm{g}}+N_{\mathrm{w}}\right)$ & & $(0.00-0.01)$ \\
typical gynes within females & & & $0.007 \pm 0.010$ \\
\hline$z_{\text {min }}$ & $N_{\min } /\left(N_{\mathrm{g}}+N_{\mathrm{w}}\right)$ & & \\
miniature gynes within females & & & \\
\hline & & & \\
\hline
\end{tabular}

using log-transformed variables. The log number of brood combs was also used as a covariate, adjusting for the particular independent variable in the linear regression model.

\section{RESULTS}

A total of 274 brood combs were examined in RCA $(n=141)$ and RCP $(n=133)$ (Tab. I). Within RCA, workers were produced in $100 \%$ of the brood combs, gynes in $92 \%$ and males in only $54 \%$. The corresponding figures for RCP were: workers $98 \%$, gynes $29 \%$, and males $62 \%$.

\subsection{Ratio allocations}

Ratio allocations of RCA and RCP are shown in Table III. Ratio allocations to males $\left(p_{\mathrm{m}}\right)$ and females $\left(1-p_{\mathrm{m}}\right)$ are complementary, thus their analyses mirror each other, which is also true in other pairs of ratios, where such complementarity is explicit in the notation. Difference in $p_{\mathrm{m}}$ between groups was almost significant (MW $Z=1.913, P=0.056$ ), although a significant difference in variance was present $(F=7.035, P=0.010)$. In addition, the majority of the variation present was between groups $(M S=0.124)$, rather than between species $(M S=0.054)$. Variability in $p_{\mathrm{m}}$ was larger for RCA $(C V=138.9 \%)$ than for $\mathrm{RCP}(C V=88.6 \%)$ and variability in $1-p_{\mathrm{m}}$ was slight for both RCA $(C V=12.4 \%)$ and $\mathrm{RCP}(C V=17.8 \%)$.

A significant difference between groups was found in ratio allocation to gynes within females ( $z$ ) (MW $Z=6.913, P=0.0005$ ) and in variance $(F=16.439, P=0.0005)$. Most of the variation present was attributable to differences between groups $(M S=0.084)$, rather than among species $(M S=0.002)$. Variability in $z$ was higher within RCP $(C V=127.2 \%)$ than within RCA $(C V=51.9 \%)$. The ratio allocation with the smallest degree of variation among all was $1-z$ (RCA: $C V=4.4 \%$; RCP: $C V=1.1 \%)$.

The fraction of gynes within females $(z+$ s.d., $n$ colonies, cells) for each species was: $\bar{M}$. asilvai $(z=0.0859 \pm 0.0504, n=14,1719)$, 
M. bicolor $(z=0.0637 \pm 0.0298, n=18$, 11745), M. subnitida $(z=0.0840 \pm 0.0404$, $n=29,2523)$, P. remota $(z=\overline{0} .0012 \pm$ $0.0012, n=5,11184)$, S. quadripunctata $(z=0.0103 \pm 0.0113, n=19,14578)$. In addition, both $\bar{P}$. remota and $S$. quadripunctata produced typical queens (typ) besides miniature queens $(\mathrm{min})$. The two kinds of queens, reared, respectively, in royal and normal cells were examined separately $\left(P\right.$. remota: $z_{\mathrm{typ}}=$ $0.0010 \pm 0.0004, z_{\min }=0.0001 \pm 0.0001$; S. quadripunctata: $z_{\mathrm{typ}}=0.0013 \pm 0.0005$, $\left.z_{\min }=0.0090 \pm 0.0024\right)$. Also, giant males were occasionally produced in royal cells in $P$. remota $(n=2)$ and $S$. quadripunctata $(n=4)$.

No difference between groups was found in ratio allocations to workers $\left(p_{\mathrm{w}}\right)$ ( $\mathrm{MW} Z=$ $0.244, P=0.807)$, but a significant difference in variances was present $(F=5.467$, $P=0.022)$. The majority of variation was among species $(M S=0.057)$, rather than between groups $(M S=0.008)$. Variability in $p_{\mathrm{w}}$ was slight in both RCA $(C V=13.8 \%)$ and $\operatorname{RCP}(C V=17.6 \%)$. Variability in $1-p_{\mathrm{w}}$ was similar for RCA $(C V=76.3 \%)$ and RCP $(C V$ $=83.4 \%)$.

Sex allocation examined as a ratio variable $(1-q$, or males within reproductives, the complement of $q$, or gynes within reproductives) showed significant difference between groups (MW $Z=4.420, P=0.0005$ ), but no difference in variances $(F=0.018, P=$ 0.895 ). Accordingly, the major part of the variation present was attributable to groups $(M S=$ 2.697) and much less variation was present among species $(M S=0.206)$. Variability was larger within RCA $(C V=89.6 \%)$ than within $\operatorname{RCP}(C V=47.6 \%)$.

Ratio allocations to gynes $\left(p_{\mathrm{g}}\right)$ were significantly different between groups (MW $Z=$ $6.942, P=0.0005)$ and there was also a significant difference in variances $(F=14.447, P=$ $0.0005)$. Indeed most of the variability present was between groups $(M S=0.070)$ and it was slight between species $(M S=0.001)$. Variability in $p_{\mathrm{g}}$ was much higher within RCP $(C V=$ $133.3 \%)$ than within RCA $(C V=53.3 \%)$.

\subsection{Numerical investment in males and females}

The numerical investment in females was higher in RCA than in RCP. The slopes $b$ of both regressions were significantly different (Tab. IV). The coefficients of determination, $R^{2}$, for the relationship between the number of females and the number of cells indicated low variability about the line and, thus, little variation between colonies and species for both RCA and RCP. The intercepts $a$ were not significantly different from zero, which would justify a regression through the origin.

The relationship between the number of males and number of cells (Tab. IV) had considerable amounts of unexplained variance for both RCA (53.4\%) and RCP (22.4\%), indicating variation either between species or colonies or both. The investment in males was nearly 3.8 times higher in RCP, as revealed by $b$ values. Some caution is necessary in the interpretation because males are known to be produced in certain periods and sampling bias could also explain this large difference between groups.

\subsection{Numerical investment in gynes and workers}

There was a significant difference between the slopes of RCA and RCP for the linear regression between the number of workers and the number of females (Tab. IV). The intercept for RCP differed from zero, while for RCA it did not. The coefficients of determination were extremely high, showing practically no variation between either species or colonies for RCA and RCP.

The linear regression between the number of gynes and number of females (Tab. IV) was significant for RCA only and the gynes comprised $6.6 \%$ of RCA females, but only $0.1 \%$ of RCP females, a 65 -fold difference. The intercept deviated from zero only in RCP.

The fraction of females that become gynes $(z)$ and the fraction of females that become workers $(1-z)$ are basic variables in the Wenseleers et al. (2003) model. The relationship between the proportional allocations 
Table IV. Linear regression parameters $( \pm s d)$, and comparison of slopes ( $t$-tests) for numerical allocations of RCA and RCP (see text for acronims). The number of colonies for RCA and RCP are, respectively, $n=61$ and $n=24$. Asterisks indicate probabilities associated with slope $(b)$ and intercept $(a)$ being different from zero, as well as significant comparisons ( $d f=81$ in all of them): $* P<0.05, * * P<0.01$, *** $P<0.001$. A strict Bonferroni adjustment leads to an experimentwise error $\alpha / 12=0.0042$.

\begin{tabular}{|c|c|c|c|}
\hline Numerical allocation & RCA & $\mathrm{RCP}$ & Comparison \\
\hline Females & $a=0.070 \pm 4.630$ & $a=76.649 \pm 44.462$ & $t=6.61^{* * *}$ \\
\hline vs. & $b=0.924 \pm 0.011 * * *$ & $b=0.711 \pm 0.033 * * *$ & \\
\hline Cells & $R^{2}=0.99 \overline{2}$ & $R^{2}=0.95 \overline{4}$ & \\
\hline Males & $a=0.070 \pm 4.630$ & $a=-76.649 \pm 44.462$ & $t=6.61 * * *$ \\
\hline vs. & $b=0.076 \pm 0.011^{* * *}$ & $b=0.289 \pm 0.033^{* * * *}$ & \\
\hline Cells & $R^{2}=0.46 \overline{6}$ & $R^{2}=0.77 \overline{6}$ & \\
\hline Males & $a=1.938 \pm 4.985$ & $a=-53.957 \pm 64.103$ & $t=5.26^{* * *}$ \\
\hline vs. & $b=0.074 \pm 0.012 * * *$ & $b=0.343 \pm 0.063 * * *$ & \\
\hline Females & $R^{2}=0.379$ & $R^{2}=0.57 \overline{7}$ & \\
\hline Gynes & $a=0.894 \pm 1.622$ & $a=-4.604 \pm 1.183^{* *}$ & $t=13.94 * * *$ \\
\hline vs. & $b=0.066 \pm 0.004 * * *$ & $b=0.001 \pm 0.001$ & \\
\hline Females & $R^{2}=0.821$ & $R^{2}=0.03 \overline{4}$ & \\
\hline Workers & $a=-0.894 \pm 1.622$ & $a=-4.604 \pm 1.183^{* *}$ & $t=14.41 * * *$ \\
\hline vs. & $b=0.934 \pm 0.004 * * *$ & $b=1.001 \pm \overline{0} .001 * * *$ & \\
\hline Females & $R^{2}=0.999$ & $R^{2}=1.000$ & \\
\hline Gynes & $a=1.218 \pm 1.733$ & $a=4.624 \pm 1.177^{* *}$ & $t=13.23 * * *$ \\
\hline vs. & $b=0.069 \pm 0.005^{* * *}$ & $b=0.001 \pm 0.001$ & \\
\hline Workers & $R^{2}=0.795$ & $R^{2}=0.03 \overline{6}$ & \\
\hline Gynes & $a=-1.041 \pm 4.116$ & $a=-300.250 \pm 84.417^{* *}$ & $t=2.09^{*}$ \\
\hline vs. & $b=1.239 \pm 0.142 * * *$ & $b=-17.656 \pm 17.055$ & \\
\hline Males & $R^{2}=0.563$ & $R^{2}=0.046$ & \\
\hline Males & $a=2.461 \pm 5.051$ & $a=-52.527 \pm 63.820$ & $t=4.99 * * *$ \\
\hline vs. & $b=0.077 \pm 0.013 * * *$ & $b=0.343 \pm \overline{0} .063 * * *$ & \\
\hline Workers & $R^{2}=0.360$ & $R^{2}=0.57 \overline{8}^{-}$ & \\
\hline Reproductives & $a=0.449 \pm 5.425$ & $a=-72.016 \pm 44.392$ & $t=4.59^{* * *}$ \\
\hline vs. & $b=0.138 \pm 0.012 * * *$ & $b=0.289 \pm 0.033^{* * *}$ & \\
\hline Cells & $R^{2}=0.678$ & $R^{2}=0.77 \overline{6}$ & \\
\hline Workers & $a=-0.449 \pm 5.425$ & $a=72.016 \pm 44.392$ & $t=4.59^{* * *}$ \\
\hline vs. & $b=0.862+0.012 * * *$ & $b=0.711+0.033 * * *$ & \\
\hline Cells & $R^{2}=0.988$ & $R^{2}=0.955$ & \\
\hline Reproductives & $a=3.678 \pm 6.239$ & $a=-47.903 \pm 63.699$ & $t=3.61^{* * *}$ \\
\hline vs. & $b=0.146 \pm 0.016^{* * *}$ & $b=0.342 \pm 0.062 * * *$ & \\
\hline Workers & $R^{2}=0.571$ & $R^{2}=0.57 \overline{7}$ & \\
\hline Gynes & $a=-0.519 \pm 1.468$ & $a=-4.633 \pm 1.123^{* * *}$ & $t=1.52$ \\
\hline vs. & $b=0.006 \pm 0.003 * * *$ & $b=0.001 \pm 0.001$ & \\
\hline Cells & $R^{2}=0.854$ & $R^{2}=0.042$ & \\
\hline
\end{tabular}

to gynes within females $(z)$ and males $\left(p_{\mathrm{m}}\right)$ was also examined. As a basic assumption of that model, such variables are assumed to be negatively correlated. A non-significant positive correlation within RCA $\left(r_{\mathrm{S}}=0.241, P=\right.$ $0.062, n=61$ ) and an absence of correlation within RCP $\left(r_{\mathrm{S}}=0.103, P=0.630, n=24\right)$ were found. In neither RCA nor RCP was there a correlation between the proportional alloca- tion to males $\left(p_{\mathrm{m}}\right)$ and workers within females $(1-z)$, as the negative trend was not significant (respectively, $r_{\mathrm{S}}=-0.208, P=0.107, n=61$ and $\left.r_{\mathrm{S}}=-0.042, P=0.846, n=24\right)$.

\subsection{Numerical investment in workers and reproductives (non-workers)}

The relationship between the number of workers and the number of cells was isometric, 
i.e. linear, in RCA (log-transformed variables, $b=1.013,95 \% \mathrm{CI}=0.970-1.055)$. This relationship was slightly, but significantly allometric for RCP (log-transformed variables, $b=0.924,95 \% \mathrm{CI}=0.852-0.995)$. However, as such allometry was expressed very little, the linear regression approximation resulted in a negligible $1.5 \%$ loss in explained variance. The numerical investment in workers was significantly higher in RCA, and the intercepts for both groups did not differ from zero. The variation in the number of cells explained more than $95 \%$ of the variance in the number of workers in both groups, hence little variance among species (Tab. IV). However, the groups differed significantly in their investment in reproductives (non-workers). This investment was approximately two times higher in RCP compared to RCA. Appreciable amounts of variance remained unexplained by the regression (low $R^{2}$ values).

\subsection{Non-hierarchical numerical investment in workers, gynes and males}

There was no correlation between the number of gynes and the number of cells in RCP, but there was a significant correlation between these variables for RCA (Tab. IV). Similarly, the number of gynes and number of males were not correlated in RCP, but they were in RCA (Tab. IV). The number of gynes corresponded to only $6 \%$ of the cells in RCA and a still smaller fraction of the cells in RCP $(0.08 \%)$. The number of males was correlated with the number of workers in both RCA and RCP (Tab. IV).

In both groups, negative correlations were found between residual allocations to males and workers (RCA: $r_{\mathrm{S}}=-0.822, P=0.0005$, $n=61$; RCP: $r_{\mathrm{S}}=-0.940, P=0.0005$, $n=24$ ), hence providing evidence of an opportunity cost. There was a negative correlation between residual allocations to gynes and workers in RCA $\left(r_{\mathrm{S}}=-0.438, P=0.0005\right.$, $n=61)$, but not in RCP $\left(r_{\mathrm{S}}=-0.014\right.$, $P=0.949, n=24)$, which lends support to the Wenseleers et al. (2003) model in this nonhierarchical framework. No significant corre- lations between the residual allocations to gynes and to males were found within the groups (RCA: $r_{\mathrm{S}}=0.038, P=0.768, n=61$; RCP: $\left.r_{\mathrm{S}}=0.092, P=0.668, n=24\right)$, suggesting an absence of opportunity cost.

\subsection{Reproductive allocation and sex allocation}

A positive correlation between the residuals of the log number of reproductives regressed on the log number of cells and the residuals of the log number of males on the log number of reproductives was found in $\mathrm{RCA}\left(r_{\mathrm{S}}=0.420\right.$, $P=0.001, n=61)$, but not in RCP $\left(r_{\mathrm{S}}=\right.$ 0.030, $P=0.891, n=24$ ).

\section{DISCUSSION}

Colony growth may be represented by a very simple equation: $N_{\mathrm{t}+1}=N_{\mathrm{t}}+$ Births Deaths - Swarms - Males. The standing stock of workers is therefore of paramount importance in determining births, because the workers provide opportunities for the queen to lay eggs by building brood cells. In other terms, the standing stock of workers is translated into the recruitment of adults. The equation above also makes clear the limitations involved in dealing solely with one component of growth, viz. recruitment.

The comparison between RCP and RCA species suffers the intrinsic limitation that these species may differ in attributes other than the main trait analysed; presence vs. absence of royal cells. Ideally the best comparison would be between very closely related species which only differed in the trait of interest. This is admittedly not the case here and general phylogenetic constraints can always be invoked as an explanation for the differences in allocation we uncovered. However, the full power of comparative analysis using independent contrasts must await a comprehensive phylogeny of stingless bees. With these caveats in mind, we attempted to provide functional explanations for the differences between the two groups. 


\subsection{Numerical investment in workers}

The lower investment in females within RCP species is accompanied by generally larger maximum colony sizes (e.g. Michener, 1974; Tóth et al., 2004). So, how is it that, despite a lower investment in females, and hence in workers, RCP species end up with larger colonies than RCA? This could be due to higher rate of brood cell construction by workers associated with higher rate of oviposition by the queen (c.f. Kerr, 1969; van Benthem et al., 1995), given that worker mortality is similar in both groups and swarming frequency is lower in RCA (Velthuis et al., 2005). Indeed, Sakagami (1982) suggested that there could be a direct relationship between the number of ovarioles in queens (which presumably would reflect oviposition rate) and colony size in stingless bees. In both RCP species studied, queens tend to have a larger number of ovarioles [four to eight: $P$. remota $(n=3)$, four to nine: $S$. quadripunctata $(n=30)]$ than RCA [four in M. bicolor $(n=1)$ and M. quadrifasciata $(n=3)$ ] (Camargo, 1974; Cruz-Landim et al., 1998).

The very high $R^{2}$ of the relationship between number of workers and number of cells indicates very little variability between species and colonies within both RCA and RCP, implying tight control over allocation to workers. Wilson (1985) reported such allocation constancy in other hymenopterans in support for a genetic control. In addition, workers were reared in practically all of the studied brood combs, further demonstrating their crucial ergonomic role and the strictness of allocation rules.

The minimum observed ratio allocations of workers for RCA $\left(p_{\mathrm{w}}=0.47\right)$ and RCP $\left(p_{\mathrm{w}}=0.59\right)$ can be plausibly interpreted as the lower thresholds which still allow for continued maintenance and survival of colonies. But it is not known whether these are indeed absolute minima, nor for how long such low ratio investments can be maintained for the sustained production of reproductives (see Velthuis et al., 2005) without putting colony survival at risk.

In both RCA and RCP a significant negative correlation was found between allocation to males and to workers, which was also found by Moo-Valle et al. (2004) in M. beecheii. The opportunity cost, basically a trade-off which seems prevalent in both groups of species, is that between males and workers. Modeling should reflect this basic opportunity cost, which was here very clear and consistent. Male production may entail such opportunity costs as to even hinder colony growth and colony fission.

The opportunity costs of producing gynes, as opposed to males and workers, are fundamental assumptions of the Wenseleers et al. (2003) model of caste determination in swarm founding hymenopteran species. These costs are treated as negative correlations between allocations to gynes within females vs. workers within females $(z$ vs. $1-z$ ) and gynes within females vs. males ( $z$ vs. $p_{\mathrm{m}}$ ). Due to the complementarity between $z$ and $1-z$, their correlation is $r=-1$ by definition (but see below), and this leaves only the correlation between the allocations to gynes within females and males subject to empirical verification. The assumption was not supported by our data. However it can be argued that these assumptions are strictly valid within-species, and our tests comprised groups of species of RCA and RCP. On the other hand it might also be expected that these correlations should show similar trends for each species and, hence, for the pooled species in each group.

It was only in RCA species which produced a considerable amount of gynes, that a negative correlation between residual allocations to gynes and workers was found. Again this entails an opportunity cost, which is rendered especially relevant because the excess gynes are killed by workers (ImperatrizFonseca and Zucchi, 1995; Koedam et al., 1995; Wenseleers et al., 2004a), thus evidencing actual conflict, and a clear waste of resources at colony level. Thus the basic assumption of an opportunity cost in the production of gynes vs. workers envisaged by the Wenseleers et al. (2003) model is supported within this alternative framework of non-hierarchical numerical allocation. 


\subsection{Numerical investment in males}

The proportional allocation to males was much higher in RCP, and the enhanced allocation to males could be due to an escalation in conflict over male parentage between queen and workers, leading to an increase in male production by both parties (see Velthuis et al., 2005). However, available data on these RCP species indicate very low (0-3\%) worker maternity of males (Hammond and Keller, 2004; Tóth et al., 2004). In this respect, the hypothesis of Ratnieks (1988) and Bourke (1999) linking low levels of worker reproduction with increased productivity and larger colony sizes might apply to these RCP, as the collated data of Hammond and Keller (2004) and Tóth et al. (2004) also show a significant difference in maximum population sizes of RCA $(n=9)$ and RCP $(n=23)$ (MW $Z=2.863, P=$ 0.003).

Data on male parentage indicate that a higher proportion of males are workers' sons in M. bicolor and M. subnitida than in P. remota and S. quadripunctata; no data exists for M. asilvai (see Tóth et al., 2004). The negative correlation between allocations to workers and males, associated with the general occurrence of worker reproduction, makes it tempting to suggest that in RCA these factors are connected in such a way as to result in RCA species having relatively small colony sizes. It is noteworthy that, within Melipona, $M$. beechei has both large maximum colony size and lacks worker reproduction (Paxton et al., 2001).

Flanders (1965) suggested a direct relationship between queen oviposition rate and the proportional allocation to males, i.e. the rate of haploid egg laying. This is not supported by limited data available on the oviposition by a single $M$. favosa queen $\left(r_{\mathrm{S}}=0.089, P=\right.$ $0.493, n=62$, assuming first order autocorrelated errors; Koedam, 1999) or from collated data on daily oviposition of five Melipona species $\left(r_{\mathrm{S}}=0.214, P=0.444, n=15\right.$; Kerr, 1969; Koedam, 1999; Sommeijer et al., 1999; Moo-Valle et al., 2001; Koedam et al., 2005).

Another explanation for the higher allocation to males in RCP links the investment to workers to that of reproductives in both groups. Thus, if there is a minimum threshold investment in workers below which colony survivorship is put at risk, this would imply a complementary maximum threshold for the investment in reproductives. According to this view, the investment in reproductives is mostly in males in RCP, while in RCA an appreciable proportion of the total investment is in gynes. Thus, the observed difference in male allocation between RCA and RCP would be due, basically, to a functional constraint related to a minimum necessary investment in maintenance, common to both groups.

\subsection{Numerical investment in gynes}

Caste conflict theory assumes substantial colonial costs to the high rate of gyne production in Melipona and of miniature gyne production in Plebeia and Schwarziana (Bourke and Ratnieks, 1999; Ratnieks, 2001; Wenseleers et al., 2003). We recognize the costs due to gyne production in excess of that theoretically predicted for swarm founding species, but envision there may be collateral benefits accruing from such a pattern of gyne production. Thus, we agree with Kerr and Nielsen (1966) and Michener (1974), who viewed the continuous production of gynes due to the genetic system of caste determination in Melipona (Kerr, 1950a, b) as enhancing the probability of survival of colonies, which in turn can lead to a larger number of reproductive opportunities, despite the costs involved. This idea hinges on whether reproductive gains from longer colony life expectancy can more than counter-balance the costs incurred due to excessive gyne production which, as suggested by the opportunity cost analysis, may be not as great as previously thought. It is suggested here that royal cells, which are functionally linked to trophogenic caste determination, do allow a high degree of accuracy and precision in the number of queens reared and on the timing of their production. When combined with the presence of genetically determined gynes (as frequently produced miniature queens), these two mechanisms of queen production have a side-effect reduction in the probability of extinction of 
RCP colonies. However, this system is not necessarily more efficient than that of RCA. In these two RCP species the proportional investment (and hence their cost) in miniature queens is much lower than the investment in gynes in the RCA, probably due to the presence of the additional trophogenic system of caste determination (see Wenseleers et al., 2004b). Notably, the range of observed $z$ values for RCA species is an order of magnitude higher than that of RCP, considering both gyne phenotypes together or separately. In turn, the allocation to typical gynes reared in royal cells, miniature gynes or both combined in RCP is one to two orders of magnitude higher than in those species which only raise gynes in royal cells, e.g. Tetragonisca angustula $(z=0.000082$ to $z=0.00027$; van Veen and Sommeijer, 2000), Trigona ventralis $(z=0.0008$; Chinh and Sommeijer, 2005).

\subsection{Sex allocation: numerical investment and ratio allocation}

Actual conflicts over sex allocation have to be approached from a population wide perspective and may be difficult to analyse for swarm founding species (e.g. Macevicz, 1979; Pamilo, 1991) due to difficulties in estimating actual sex investment, which should include investment in workers. Here, sex ratio simply focused males and gynes. The secondary sex ratio measured at adult recruitment does not reflect the operational sex ratio at mating (see Velthuis et al., 2005).

The patterns of allocation to males and gynes in RCA and RCP are strikingly different and as a consequence, sex allocation has to be viewed in this perspective. No correlation between residual allocations to gynes and males was found in either RCA or RCP species and, therefore, no opportunity costs between these reproductives were found. Neither were opportunity costs found in $M$. beecheii (Moo-Valle et al., 2001, 2004).

Sex ratios were strongly biased towards gynes in RCA and towards males in RCP. Sex ratios estimated from males and gynes only may actually underestimate female investment in swarm founding species (Chapuisat and Keller, 1999). Recent modeling on caste determination in swarm founding species (Wenseleers et al., 2003) formalized previous suggestions made by Craig (1980) and Bourke and Ratnieks (1999) that queen and workers are aligned in their interests and favour the production of few queens $(z \sim 0$, in their model). Hence a male biased sex ratio would be expected. This is indeed what was observed in RCP, considering only males and typical gynes, excepting miniature queens, which can be considered as queen overproduction above colonial needs (Wenseleers et al., 2003) and slightly bias the sex ratio estimation. As already discussed, in RCA the continuous queen production over that expected from theory for swarm founding species results in a high probability of colony survivorship through enhanced probability of quick queen replacement. This benefit can outweigh, in the long term, the costs due to decreased production of males and workers.

Unfortunately, until estimates of the number of workers in swarms for these RCA and RCP species are available, classical FisherianHamiltonian sex ratio theory (Hamilton, 1975; Trivers and Hare, 1976) cannot be strictly applied to swarm founding species. It is noteworthy that Pamilo (1991) predicted male-biased sex ratios even when workers are counted as an investment in females, if there is local resource competition. Considering the numerical investment by RCA, as reflecting actual sex investment because all individuals are reared in equal-sized cells, their sex ratio would seem not as predicted by Pamilo (1991), but local resource competition would need to be demonstrated for such a conclusion to hold.

Herbers et al. (2001) suggested that variance between colonies be used to distinguish queen vs. worker control of sex ratios. Here, $C V$ was used to examine the degree of variability in sex ratio. The higher variability in RCA sex ratio between colonies cannot be directly equated with split sex ratios because the energetic investment per se is necessary, and also because workers have not been included. Despite the high allocation to males, no correlation was found between reproductive and sex allocations in RCP. This is due to the absence of variability in RCP sex ratio, practically a 
male:male ratio, given the low investment in gynes.

\section{ACKNOWLEDGEMENTS}

We thank three anonymous referees, Dr. K. Hartfelder and Dr. J. Biesmeijer for valuable comments on the manuscript. DAA and VLIF had grants from CNPq (Conselho Nacional de Desenvolvimento Científico e Tecnológico).

Résumé - Investissement numérique dans les sexes et les castes chez les abeilles sans aiguillon (Apidae : Meliponini) : analyse comparative. L'investissement dans le nombre d'ouvrières, de gynes (jeunes reines non fécondées), et de mâles a été étudiée chez certaines espèces d'abeilles sans aiguillon. Nous avons essayé de mettre en relief l'importance des ouvrières chez ces insectes sociaux dont les colonies sont fondées par un essaim, en raison de leurs rôles dans la maintenance et la croissance de la colonie et dans l'essaimage. L'approche choisie se base sur la structure de modèles de l'affectation des ressources publiés par Pamilo (1991), Reuter et Keller (2001), Wenseleers et al. (2003).

On a confronté les espèces qui construisent des cellules royales (RCP : Plebeia remota et Schwarziana quadripunctata) et celles qui n'en construisent pas (RCA : Melipona asilvai, M. bicolor et M. subnitida) eu égard aux affectations en proportions et en nombres dans les sexes et les castes. La production d'individus a été étudiée par l'examen des nymphes vivantes dans les rayons de couvain (unités d'échantillonnage, Tab. I). Le nombre total de cellules est la somme des gynes, des mâles et des ouvrières et peut être représenté par un modèle additif de régression linéaire pour estimer l'investissement en nombre (Tab. II).

Chez les espèces RCA, les femelles sexuées, les mâles et les ouvrières sont produits dans $92 \%, 54 \%$ et $100 \%$ respectivement des rayons de couvain $(\mathrm{n}=$ 141); pour les espèces RCP, les chiffres sont de $29 \%, 62 \%$ et $98 \%$. Il y a des différences significatives entre les groupes dans les affectations en proportion (Tab. III) aux gynes $\left(p_{\mathrm{g}}\right)$, aux gynes au sein des femelles $(z)$, aux ouvrières au sein de femelles $(1-z)$ et aux mâles au sein des individus reproducteurs (sex-ratio), mais pas dans les affectations en proportion aux mâles $\left(p_{\mathrm{m}}\right)$, aux ouvrières $\left(p_{\mathrm{w}}\right)$, aux femelles $\left(1-p_{\mathrm{m}}\right)$ et aux individus reproducteurs $\left(1-p_{\mathrm{w}}\right)$. Les espèces RCA ont présenté des valeurs plus élevées que les RCP seulement pour $p_{\mathrm{g}}$ et $z$. On a examiné la relation entre $z$ et $p_{\mathrm{m}}$, comme dans Wenseleers et al. (2003). On a trouvé une tendance vers une corrélation positive pour les espèces RCA $(P=0,062)$, mais rien pour les espèces RCP. Aucun des groupes n'a montré de corrélation entre l'affectation proportionnelle à $p_{\mathrm{m}}$ et $1-z$.
Les pentes des régressions linéaires entre couples de variables ont montré des investissements en nombre différents entre groupes (Tab. IV). Chez les espèces RCA les pentes (en nombres proportionnels) ont été significativement plus élevées pour les couples femelles/cellules, gynes/femelles, gynes/mâles et ouvrières/cellules. Chez les espèces RCP elles étaient significativement plus élevées pour les couples mâles/cellules, mâles/femelles, ouvrières/femelles, gynes/ouvrières, mâles/ouvrières, individus reproducteurs/cellules et individus reproducteurs/ouvrières. Aucune différence significative n'a été trouvée entre les pentes pour le couple gynes/cellules. Les espèces RCA ont eu un investissement en nombre plus important dans les gynes que les RCP $(6,0 \%$ contre $0,08 \%$ des cellules totales).

Dans les deux groupes des corrélations négatives ont été trouvées entre les affectations résiduelles aux mâles par rapport aux ouvrières. Il y a une corrélation négative entre les affectations résiduelles aux gynes par rapport aux ouvrières chez les espèces RCA mais pas chez les RCP, ce qui corrobore le modèle de Wenseleers et al. (2003). Aucune corrélation significative entre les affectations résiduelles aux gynes par rapport aux mâles n'a été trouvé dans aucun des groupes. Il y a une corrélation positive entre les résiduelles du Log du nombre d'individus reproducteurs et le Log du nombre de cellules.

En dépit d'un investissement plus faible dans les femelles, les espèces RCP finissent en général avec des colonies plus importantes que les RCA. Ce peut être dû au taux de mortalité plus faible et/ou au taux plus élevé de construction des cellules de couvain et de la ponte de la reine. Une relation non linéaire entre les ouvrières et les cellules n'a été trouvée que chez les espèces RCP, ce qui suggère une affectation proportionnelle variable dépendant de la taille de la colonie. Les espèces RCP ont une affectation proportionnelle plus élevée pour les mâles. Dans les deux groupes, la corrélation négative entre mâles et ouvrières suggère un coût d'opportunité qui peut empêcher la croissance de la colonie et/ou sa fission.

Meliponini / abeille sans aiguillon / sex ratio / production d'ouvrières / affectation numérique

\footnotetext{
Zusammenfassung - Zahlenmässige Investition in Geschlechtstiere und Kaste bei Stachellosen Bienen (Apidae: Meliponini): eine vergleichende Untersuchung. Wir untersuchten die zahlenmässige Investition in Arbeiterinnen, Jungköniginnen und Männchen bei einigen Arten Stachelloser Bienen. Ziel war es, die Bedeutung von Arbeiterinnen in diesen sich durch Schwarmverhalten reproduzierenden eusozialen Bienen zu erfassen und insbesondere die Bedeutung der Arbeiterinnen im Wachstum und der Erhaltung der Kolonien, sowie im
} 
Schwarmvorgang herauszustellen. Der gegenwärtige Ansatz liegt im Rahmen publizierter Modelle zur Mittelzuweisung (Ressourcen-Allokation) (Pamillo, 1991; Reuter und Keller, 2001; Wenseleers et al., 2003).

Dabei stellten wir Arten, die Königinnenzellen bauen (RCP: Plebeia remota und Schwarziana quadripunctata) solchen Arten gegenüber, die keine speziellen Königinnenzellen bauen (RCA: Melipona asilvai, M. bicolor und M. submitida), und wir betrachteten die proportionale und numerische Investition in Geschlecht und Kaste durch die Analyse lebender Puppen in Brutwaben als Sammeleinheiten (Tab. I). Die Gesamtzahl der Brutzellen pro Brutwabe stellt die Summe der Jungköniginnen, Männchen und Arbeiterinnen dar, und diese kann in einem additiven linearen Regressionsmodell dargestellt werden, um die zahlenmässigen Investitionen zu erfassen.

RCA-Arten produzierten in $92 \%$ der Brutwaben Jungköniginen, in $54 \%$ waren Männchen zu finden und alle Brutwaben $(100 \%, \mathrm{n}=141)$ enthielten Arbeiterinnenpuppen. Bei den RCP-Arten lagen die entsprechenden Werte bei $29 \%, 62 \%$ und $98 \%$ $(\mathrm{n}=133$ Brutwaben). Die beiden Gruppen zeigten signifikante Unterschiede in den proportionalen Investitionsraten (Tab. III) in Jungköniginnen $(p g)$, in Jungköniginnen in Bezug zur Weibchenzahl in der Brut $(z)$, in Arbeiterinnen zur Weibchenzahl $(1-z)$ und in Männchen in Bezug auf die Zahl der Geschechtstieren (Geschlechts-Allokation). Keine Unterschiede waren hingegen zu finden hinsichtlich der proportionalen Allokation in Männchen $(\mathrm{pm})$, Arbeiterinnen $(p w)$, Weibchen $(1-p m)$ und in Geschlechtstiere $(1-p w)$. Bei RCA-Arten waren die Werte für $p g$ und $z$ erhöht im Vergleich zu RCPArten, und wenn wir die Beziehung von $z$ zu pm analysierten (vgl., Wenseleers, 2003) zeigte sich eine positive Korrelation bei RCA-Arten $(P=0,062)$ aber nicht bei RCP-Arten. Keine der beiden Gruppen zeigte eine Korrelation zwischen den proportionalen Investitionen in $p m$ und $1-z$.

Die Steigungen der linearen Regressionen zwischen Variablenpaaren wies auf Unterschiede in der numerischen Investition zwischen den beiden Gruppen hin (Tab. IV). Bei RCA-Arten waren die Steigungen (in Verhältniszahlen) bei folgenden Variablenpaaren signifikant höher: Weibchen gegen Gesamtzahl der Brutzellen, Jungköniginnen gegen Weibchen, Jungköniginnen gegen Männchen und Arbeiterinnen gegen Brutzellen. Bei RCPArten waren die Steigungen signifikant höher für: Männchen gegen Brutzellen, Männchen gegen Weibchen, Arbeiterinnen gegen Weibchen, Jungköniginnen gegen Arbeiterinnen, Männchen gegen Arbeiterinnen, Geschlechtstiere gegen Brutzellen und Geschlechtstiere gegen Arbeiterinnen. Keine signifikanten Unterschiede in den Steigungen waren für Jungköniginnen gegen Brutzellen zu finden, allerdings war die numerische Investition in Jungköniginnen bei RCA-Arten $(6,0 \%)$ wesentlich hö- her als bei RCP-Arten (in 0,08 \% der Gesamtzahl der Brutzellen).

Beide Gruppen zeigten eine negative Korrelation in den residualen Allokationen in Männchen zu Arbeiterinnen. Die Tatsache, dass wir für RCA- aber nicht für RCP-Arten eine negative Korrelation in den residualen Allokationen von Jungköniginnen zu Arbeiterinnen fanden, unterstützt das Modell von Wenseleers et al. (2003). Keine der beiden Gruppen zeigte hingegen eine negative residuale Allokation für Jungköniginnen gegen Männchen. Positive Korrelation fanden wir für die RCA- aber nicht für die RCP-Arten hinsichtlich der Residualwerte der Logarithmen der Geschlechtstiere in Regression gegen die Logarithmen der Brutzellen, sowie in den Residualwerten der Logarithmen der Männchen in Regression gegen die Logarithmen der Geschlechtstiere.

Trotz einer geringeren Investition in Weibchen weisen RCP-Arten im Vergleich zu RCA-Arten in der Regel grössere Kolonien auf, was entweder auf eine geringere Mortalitätsrate und/oder höhere Raten im Bau von Brutzellen und der Eilagerate von Königinnen zurückzuführen sein könnte. Die nur bei RCP-Arten zu findende nichtlineare Beziehung von Arbeiterinnenzahl zu Brutzellen weist auf eine variable proportionale Allokation im Bezug zur Koloniegrösse hin. RCP-Arten zeigten ebenfalls eine höhere proportionale Investition in Männchen. Die bei beiden Gruppen nachweisbare negative Korrelation von Männchen- zu Arbeiterinnenproduktion weist auf einen starken Gelegenheitskostenfaktor hin, der das Koloniewachstum oder die Kolonieteilung negativ beeinflussen könnte.

\section{Stachellose Bienen / Meliponini / Produktion von Arbeiterinnen / numerische Allokation}

\section{REFERENCES}

Alves D.A. (2004) Produção de operárias, rainhas e machos em Melipona bicolor Lepeletier, 1836 (Apidae, Meliponini), Monografia, Universidade Presbiteriana Mackenzie, São Paulo.

Alves D.A., Ribeiro M.F., Santos-Filho P.S., Imperatriz-Fonseca V.L. (2004) Production of gynes and males in Plebeia remota Holmberg, 1903 (Apidae, Meliponini), in: Proc. 8th IBRA Int. Conf. on Tropical Bees and VI Encontro sobre Abelhas, Ribeirão Preto, p. 753.

Arias M.C., Francisco F.O., Silvestre D. (2003) O DNA mitocondrial em estudos populacionais e evolutivos de Meliponíneos, in: Melo G.A.R., Alves dos Santos I. (Eds.), Apoidea Neotropica: homenagem aos 90 anos de Jesus Santiago Moure, UNESC, pp. 203-309.

Benford F.A. (1978) Fisher's theory of the sex ratio applied to the social Hymenoptera, J. Theor. Biol. $72,701-727$. 
Boomsma J.J., Grafen A. (1991) Colony-level sex ratio selection in the eusocial Hymenoptera, J. Evol. Biol. 3, 383-407.

Bourke A.F.G. (1999) Colony size, social complexity and reproductive conflict in social insects, J. Evol. Biol. 12, 245-257.

Bourke A.F.G., Chan G.L. (1999) Queen-worker conflict over sexual production and colony maintenance in perennial social insects, Am. Nat. 154, $417-426$.

Bourke A.F.G., Ratnieks F.L.W. (1999) Kin conflict over caste determination in social Hymenoptera, Behav. Ecol. Sociobiol. 46, 287-297.

Bulmer M.G. (1983) Sex ratio theory in social insects with swarming, J. Theor. Biol. 100, 329-339.

Camargo J.M.F. (1974) Notas sobre a morfologia e biologia de Plebeia (Schwarziana) quadripunctata quandripunctata (Hymenoptera, Apidae: Meliponinae), Studia Entomol. 17, 433-470.

Chapuisat M., Keller L. (1999) Testing kin selection with sex allocation data in eusocial Hymenoptera, Heredity 82, 473-478.

Chinh T.X., Sommeijer M.J. (2005) Production of sexuals in the stingless bee Trigona (Lepidotrigona) ventralis flavibasis Cockerell (Apidae, Meliponini) in northern Vietnam, Apidologie 36, 493-503.

Costa M.A., Del Lama M.A., Melo G.A.R., Sheppard W.S. (2003) Molecular phylogeny of the stingless bees (Apidae, Apinae, Meliponini) inferred from mitochondrial 16S rDNA sequences, Apidologie 34, 73-84.

Craig R. (1980) Sex Investment ratios in social Hymenoptera, Am. Nat. 116, 311-323.

Crozier R.H., Pamilo P. (1996) Evolution of social insect colonies sex allocation and kin selection, Oxford University Press, New York.

Cruz-Landim C. da, Reginato R.D., ImperatrizFonseca V.L. (1998) Variation on ovariole number in Meliponinae (Apidae) queen's ovaries with comments on ovary development and caste differentiation, Pap. Avulsos Zool. 40, 289-296.

Flanders S.E. (1965) On the sexuality and sex-ratios of hymenopterous populations, Am. Nat. 99, 489494.

Frank S.A. (1987) Individual and population sex allocation patterns, Theor. Popul. Biol. 31, 47-74.

Hamilton W.D. (1975) Gamblers since life began: barnacles, aphid, elms, Q. Rev. Biol. 50, 175-180.

Hammond R.L., Keller L. (2004) Conflict over male parentage in social insects, PLoS Biol. 2, e248.

Herbers J.M., DeHeer C.J., Foitzik S. (2001) Conflict over sex allocation drives conflict over reproductive allocation in perennial social insect colonies, Am. Nat. 158, 178-192.
Imperatriz-Fonseca V.L., Zucchi R. (1995) Virgin queens in stingless bee (Apidae, Meliponinae) colonies: a review, Apidologie 26, 231-244.

Kerr W.E. (1950a) Evolution of the mechanism of caste determination in the genus Melipona, Evolution 4, 7-13.

Kerr W.E. (1950b) Genetic determination of castes in the genus Melipona, Genetics 35, 143-152.

Kerr W.E., Nielsen (1966) Evidences that genetically determined Melipona queens can become workers, Genetics 54, 859-866.

Kerr W.E. (1969) Some aspects of the evolution of social bees (Apidae), Evol. Biol. 3, 119-175.

Koedam D. (1999) Production of queens, workers and males in the stingless bee Melipona favosa (Apidae: Meliponinae): patterns in time and space, Neth. J. Zool. 49, 289-302.

Koedam D. (2003) A non-invasive method for sampling Melipona brood combs and determining caste and sex ratios, in: Melo G.A.R., Alves dos Santos I. (Eds.), Apoidea Neotropica: homenagem aos 90 anos de Jesus Santiago Moure, UNESC, pp. 153-156.

Koedam D., Monge I.A., Sommeijer M.J. (1995) Social interactions of gynes and their longevity in queenright colonies of Melipona favosa (Apidae: Meliponinae), Neth. J. Zool. 45, 480-494.

Koedam D., Contrera F.A.L., Imperatriz-Fonseca V.L. (1999) Clustered male production by workers in the stingless bee Melipona subnitida Ducke (Apidae, Meliponinae), Insectes Soc. 46, 387391.

Koedam D., Contrera F.A.L., Fidalgo A. de O., Imperatriz-Fonseca V.L. (2005) How queen and workers share in male production in the stingless bee Melipona subnitida Ducke (Apidae, Meliponini), Insectes Soc. 52, 114-121.

Macevicz S. (1979) Some consequences of Fisher's sex ratio principle for social Hymenoptera that reproduce by colony fission, Am. Nat. 113, 363-371.

Mehdiabadi N.J., Reeve H.K., Mueller U.G. (2003) Queens versus workers: sex ratio conflict in eusocial Hymenoptera, Trends Ecol. Evol. 18, 88-93.

Michener C.D. (1974) The social behavior of the bees, a comparative study, Belknap Press, Cambridge.

Michener C.D. (2000) The bees of the world, Johns Hopkins University Press, Baltimore.

Moo-Valle H., Quezada-Euán J.J.G., Wenselleers T. (2001) The effect of food reserves on the production of sexual offspring in the stingless bee Melipona beecheii (Apidae, Meliponini), Insectes Soc. 48, 398-403.

Moo-Valle H., Quezada-Euán J.J.G., Canto-Martín J., Gonzalez-Acereto J.A. (2004) Caste ontogeny and the distribution of reproductive cells on the combs of Melipona beecheii (Apidae: Meliponini), Apidologie 35, 587-594. 
Moure J.S. (1961) A preliminary supra-specific classification of the Old World Meliponinae bees (Hymenoptera, Apoidea), Studia Entomol. 4, 181242.

Oster G., Eshel I., Cohen D. (1977) Worker-queen conflict and the evolution of social insects, Theor. Popul. Biol. 12, 49-85.

Oster G.F., Wilson E.O. (1978) Caste and ecology in the social insects, Princeton University Press, New Jersey.

Page R.E., Metcalf R.A. (1984) A population investment sex ratio for the honey bee (Apis mellifera L.), Am. Nat. 124, 680-702.

Pamilo P. (1991) Evolution of colony characteristics in social insects, I- Sex allocation, Am. Nat. 137, 83107.

Paxton R.J., Ruhnke H., Shah M., Bego L.R., QuezadaEuán J.J.G., Ratnieks F.L.W. (2001) Social evolution in stingless bees: are the workers or is the queen in control of male parentage? in: II Seminario Mexicano Sobre Abejas Sin Aguijón, Mérida, México, pp. 104-107.

Queller D.C, Strassmann J.E. (1998) Kin selection and social insects, Bioscience 48, 165-175.

Quinn G.P., Keough M.J. (2002) Experimental design and data analysis for biologists, Cambridge University Press, Cambridge.

Ratnieks F.L.W. (1988) Reproductive harmony via mutual policing by workers in eusocial Hymenoptera, Am. Nat. 132, 217-236.

Ratnieks F.L.W. (2001) Heirs and spares: caste conflict and excess queen production in Melipona bees, Behav. Ecol. Sociobiol. 50, 467-473.

Reuter M., Keller L. (2001) Sex ratio conflict and worker production in eusocial Hymenoptera, Am. Nat. 158, 166-177.

Sakagami S.F. (1982) Stingless bees, in: Hermann H.R. (Ed.), Social insects, Vol. 3, New York, Academic Press, pp. 361-423.

Silveira F.A., Melo G.A.R., Almeida E.A.B. (2002) Abelhas Brasileiras: Sistemática e Identificação, Belo Horizonte, 253 p.
Sokal R.R., Rohlf F.J. (1998) Biometry, W.H. Freeman and Company, New York.

Sommeijer M.J., Chinh T.X., Meeuwsen F.J.A.J. (1999) Behavioural data on the production of males by workers in the stingless bee Melipona favosa (Apidae, Meliponinae), Insectes Soc. 46, 92-93.

Tóth E., Quelller D.C., Dollin A., Strassmann J.E. (2004) Conflict over male parentage in stingless bees, Insectes Soc. 51, 1-11.

Trivers R.L., Hare H. (1976) Haplodiploidy and the evolution of the social insects, Science 191, 249 263.

Tschinkel W.R. (1993) Sociometry and sociogenesis of colonies of the fire ant Solenopsis invicta during one annual cycle, Ecol. Monogr. 63, 427-457.

van Benthem F.D.J., Imperatriz-Fonseca V.L., Velthuis H.H.W. (1995) Biology of the stingless bee Plebeia remota (Holmberg): observations and evolutionary implications, Insectes Soc. 42, 71-87.

van Veen J.W., Sommeijer M.J. (2000) Colony reproduction in Tetragonisca angustula (Apidae, Meliponini), Insectes Soc. 47, 70-75.

Velthuis H.H.W., Koedam D., Imperatriz-Fonseca V.L. (2005) The males of Melipona and other stingless bees and their mothers, Apidologie 36, 169-185.

Wenseleers T., Ratnieks F.L.W., Billen J. (2003) Caste fate conflict in swarm-founding social Hymenoptera: an inclusive fitness analysis, J. Evol. Biol. 16, 647-658.

Wenseleers T., Hart A.G., Ratnieks F.L.W., QuezadaEuán J.J.G. (2004a) Queen execution and caste conflict in the stingless bee Melipona beecheii, Ethology 110, 725-736.

Wenseleers T., Hart A.G., Ratnieks F.L.W. (2004b) When resistance is useless: policing and the evolution of reproductive acquiescence in insect societies, Am. Nat. 164, E 154-167.

Wilson E.O. (1985) The sociogenesis of insect colonies, Science 228, 1489-1495.

Zar J.H. (1999) Biostatistical analysis, Prentice Hall, New Jersey. 